\begin{tabular}{l|l} 
& $\begin{array}{l}\text { Eastern } \\
\text { European } \\
\text { Countryside }\end{array}$ \\
\hline Co.1515/eec-2015-0012 & $21^{\prime} 2015$
\end{tabular}

Monika Kwiecińska-Zdrenka

\title{
The Central Eastern European Countryside Transformation - Balance of Two Decades
}

Swain N. (2013), Green Barons, Force-of-Circumstance Entrepreneurs, Impotent Mayors. Rural Change in the Early Years of Post-Socialist Capitalist Democracy, CEU Press: Budapest-New York, pp. 398.

Nigel Swain's book is an exceptional work because, above all else, it offers an amazingly wide, in-depth, complex and multidimensional analysis of changes that have taken place in rural areas in the early years of political transformation. The author himself presents its contents as "not just [...] identifying and analysing the rural social change associated with decollectivisation of agriculture in East Europe, it is also about recovering the historical moment of the change; and in six countries which approached the common project in different ways and from different starting points" (p. XIII). These discrepancies between starting points and choice of directions demanded an explanation from the author as to why ostensibly similar countries, with similar challenges, have been wrestling with them in completely different manners, and what the historical and social determinants were of the strategies chosen to deal with political transformation.

As the author himself declares, his book is both "non-disciplinary" and multidisciplinary - it contains social, economic, political and anthropological analyses. It is an extremely interesting source of knowledge for those interested in any particular country of those analysed, as well as in the whole region. 
Although it concerns rural areas in East-Central Europe (studied empirically at the beginning of the 1990s), the work can be seen as a wider study of both the great social change and reactions to that change. The author's concerns are: realizing affinities in the transformation scenarios, differences in their trajectories, and an attempt to explain social, economic and cultural reasons for the emergence of the groups of winners and losers in this transformation.

Swain uses two main arguments explaining why it is appropriate to use rural societies as examples, when expounding the development process of post-socialist formations. First of all, the author claims that rural societies constitute an "ideal locus for investigating the complexity of capitalist democracy, the interrelationship of politics, economics, the social and the cultural", mostly because these spheres are closely intertwined and in the local societies these relations are much clearer and not to be disregarded. The second reason is the presence of collective farm or agricultural producer co-operatives, which - according to Swain - reflects "two essential features of socialist production relations: the unequal powers of labour and management (the ability to manipulate labour inputs to maximize their private benefits), and the institutionalization of the symbiotic relationship between the 'first' and the 'second' economy" (pp. 3-4).

A study of 54 villages in East-Central Europe conducted at the beginning of the 1990s constitutes an empirical basis for the book. Initially (between 1993 and 1994), villages in the Czech Republic, Hungary, Poland and Slovakia (9 in each country) were subjects of the study, later complemented by 9 villages in Bulgaria and Romania (1995-1996).

In the basic attempt, 3 villages were chosen out of different areas. The areas chosen were described as "core", "periphery" (geographically remote from an economic centre) and "industrial periphery" (rural areas where there had been an industrial development under socialism, which was at risk during the transition to a market economy). Villages located in these areas were selected by country-based researchers. Villages and areas were chosen with regard to previous information the researchers had of them, to facilitate acquiring contextual information. In the village selection process, an additional criterion concerning development strategy was used, described by the researchers as "pro-agricultural", "pro-developmental" or "laissez-faire". The study was divided in terms of quantity and quality. Swain stresses that the methodology chosen was a result of pragmatic assumptions. 
The researchers were aware that they would never obtain a representative quantity, nor an in-depth, comprehensive, ethnographic quality of the material. They assumed, however, that: "researching in nine villages per country $[\ldots]$ somewhat reduces the possibility of our understanding being skewed because the chosen village is wholly uncharacteristic of the larger community" (pp. 9-10), so the qualitative method was chosen rather to permit the recovery of meanings and intentions.

Such methodological decisions allowed constructing of a convincing image of early post-socialist rural experience, "focused on the key issues of agricultural restructuring, employment and entrepreneurship in the non-farm economy, and local politics" (p. 10).

Swain has organized the results obtained in particular countries into separate chapters (chapters 3-8), highlighting the most characteristic elements of each country - in each chapter we deal with a different choice of issues, discussed with regard to the local historical, political, economic, cultural and social context. The author, however, ensured that the analyses of each country correspond to the key issues indicated. In each of these chapters we are to find answers to questions of what happened regarding the structures of socialist agriculture, what the developments of the non-farm economy were (employment, unemployment, new business formations), and what attempts were made by local government actors and others to address village problems and provide some direction of development.

The reading is facilitated by two introductory chapters and a summary at the end of the book. In the first chapter, as revealed by the author, we will find an analysis showing the initial condition of the countries studied - which political direction was chosen and what solutions were adopted concerning privatization and restitution policies, how co-operative restructuring proceeded, and which approaches were chosen to strengthen local democracy.

The second chapter, where Swain compiles study results mutual for all the countries, is particularly fascinating. He discusses the threads presented in detail in the main chapters, each devoted to a different country. Here, we are to present them briefly, with regard to five fundamental issues discussed in detail in the book.

Restructuring of agriculture: Swain indicates that in spite of differences in restructuring scenarios, a mutual element existed that has been observed in all the countries: a fragmented ownership. Fairly easy access to land made 
the opportunity of its effective use, with access to capital and machinery, more valuable than the land itself. That, in turn, gave the co-operative management (given the title "green barons") great privileges - they were the ones to have the human, social and cultural resources to capitalize on the new opportunities. "[...] The net result of these complex changes was the dual model of agriculture rather than the western European model of family farmers (but with slightly different patterns of dualism in each country) [...] with four key players: small-scale, pluriactive, self-supply oriented, often benefit-dependent producers, small to medium scale private family famers, large-scale private corporate farms ('successors' of socialist production units), 'socialist type' post-socialist transformed co-operatives" (pp. 85-87).

Non-farm economy: Socialist under-urbanisation had a consequence of high levels of commuting and non-agricultural jobs were the experience of non-agricultural work in the countryside and - as Swain claims - high levels of education. That meant that the skills and capacities could have been easily transferred to new and changing economic environments. These features, along with a weak labour market and increasing unemployment, changes concerning agriculture (which was less and less common as a professional activity among inhabitants of villages in the majority of East-Central European countries), as well as macroeconomic changes, enhanced the development of rural enterprises. These rural entrepreneurs are designated by Swain as "force-of-circumstance entrepreneurs" (p. 88), for their business activity is an outcome of two influencing factors: on one hand, it is the personal bio, enabling oneself to see one's opportunity on the broader market; on the other hand, family resources that could be assembled, supporting such business initiative, in spite of lack of institutional support. The author pays attention to the fact that such activity was often taken up in a secured manner - other family members had to have either an earned or unearned source of income.

Local government: Swain proposes a thesis, where independently of regional differences, the experiences of the early transformational period might be described by two words perfectly rendering their nature: "inexperience" and "impotence". Lack of experience was to be manifested in few ways: continuation and inertia (old leaders became new leaders), minor importance of belonging to political parties, corruption ("fuzziness' of the distinction between private interests and public sphere") and common- 
sense help distribution (pp. 99-101). Impotence towards new challenges was mainly visible in the tension resulting from new duties for local authorities, no financial insurance, focusing on developmental, especially infrastructural deficits, lack of ideas for alternative development paths, neglecting the relations between direct involvement in economic activity and the possibility of resolving problems as well as stimulating the local economy (p. 102).

Rural communities and civil society: Swain states that socialism had a similar social effect across the whole region: it isolated rural areas literally (by weak communication and telecommunication systems) and mentally (socialist paternalism). That last process resulted in a lack of motivation and involvement in common causes (involvement in social work was obligatory before). In spite of that, even at the time of the study, changes in the manner of inhabitants' organization were apparent, especially gradual independence of such associations from former institutions, with a support from private entrepreneurs and (often) in connection with political parties. According to Swain's observations, in the first period of transformation, the initial reaction of inhabitants of rural areas to economic collapse was to retract into their households, but the economic recovery facilitated more frequent manifestations of local identity (p. 109).

Swain's book is not only a perfect analysis of Central European transformations of rural areas at the beginning of the 1990s, but is also an inspiring outline for further directions in research concerning transformation of rural areas in this part of Europe.

One such inspiration was a thread that the author decided to abandon. Swain emphasized that the choice of areas to be studied was deliberate (on account of location and function of the village as well as developmental politics adopted by local authorities). At the same time, the author explains in the introduction that such categories of theoretical selection proved fruitless, while patterns and distinctive features turned out to be of minor importance to the facts established and eventually this thread (apart from its mentioning in the introduction) was not explored in the book.

Swain's book does not lose its value, however, thanks to the multidimensionality of analyses and comparisons found inside - these are conducted both diachronically and synchronically. On one hand, the author situates studied villages in time as well as in social, political and economic context. On the other hand, he places each country on a peculiar 
developmental continuum (diachronic analyses). Additionally, he compares the countries (synchronic analyses) at the moment of study.

The fact that this thread could not be explored on the basis of empirical material collected at the beginning of the 1990s is also explicable for different reasons not articulated by Swain. They can be found in two developmental features of East-Central European countries - imitational nature of political transformation (Ziółkowski) as well as proceeding from local development strategy based on informal mutual aid and engaging mass organizations to local and central programmes' strategies (Starosta 1995, p. 225).

Political transformation analysts emphasize that the changes observed at the end of the 1980s and at the beginning of the 1990s in Central European countries were an outcome of fiats and spontaneous grassroots processes, but their nature was imitational on both of these levels. Marek Ziółkowski, who formulated this thesis in relation to Polish transformation, has observed that this "mimicry" referred to two utterly different systems: "real socialism" (at the beginning of the political transformation we were dealing with revision, but also with continuation of modernization processes, with an ubiquitous state that controls but also takes responsibility for the fate of an individual, as well as with changes being introduced in a dogmatized manner) and democratic liberal capitalism, introducing contradicting ideas for reality. For, as Ziółkowski claims, attempts were made to introduce three developmental stages of capitalist societies at the same time: early modernity (free competition, investments and savings, work ethic), late modernity (demonstrative consumerism) and post-modernity (Ziółkowski 1997, pp. 76-77). These were the general transformation characteristics influencing the choice of developmental strategies, especially in the scope of aims, duties undertaken, ways of obtaining money for further development and the social mobility system.

On the local level, it has been thoroughly analysed by Pawel Starosta (Starosta 1995, pp. 225-235). Among other things, he noticed that at that time a gradual decline in mass organizations in favour of local programs (with institutional leadership, relying on bureaucratic mechanisms, often initiated by local organizations) appeared, as well as assimilation of developmental strategies on account of aims (these were mainly investment duties focused on improvement of existential conditions) and nature (defensive rather than offensive). 
Both of these processes illustrate why the early 1990s attempts to relate the observed phenomena to developmental politics of the societies studied could not bring any interesting results. It is worth noting, however, that since the time of Swain and his international team, development directions of local societies have cleared, deepening social (and especially economic) relations between core and peripheral societies at the same time. Integration with the European Union, introducing Common Agricultural Policy as well as other European policies, especially those related to regional development but also economic, social and political solutions adopted in further stages of transformation in particular countries (on both developmental impulses - such as joining the EU - and critical impulses - global economic crisis, internal economic and political crises), played a major role in this transformation. So after all, maybe it is worth considering - despite the author's declared distancing from such an idea - going back to the areas studied and verifying whether their current developmental direction is in any way connected to their initial one, studied by Swain at the time of the early post-transformational period.

Finally, the distance in time between the study (the beginning of the 1990s) and publication of the analyses in volume form (2013) gave them an additional value. The work is free from - so characteristic of the early 1990s - presentist analyses. Studies conducted in the first posttransformational years were under strong pressure to (often hurriedly) formulate theses explaining what happened in rural areas, also for the purpose of politics. In particular, the descriptions (less often explanations) indicating developmental barriers were of major pragmatic importance. They could serve (and they did) the purpose of finding solutions to these problems. Swain, thanks to his decision to delay the publication of results, had the ability to understand and explain the issues of post-transformational Central European rural areas more comprehensively in a comparative perspective, with regard to complex political, legal, historical, economic and social context.

\section{References}

Starosta P. (1995), Poza metropoliq. Wiejskie i małomiasteczkowe zbiorowości lokalne a wzory porzadku makrospołecznego [Outside of the metropolis. Rural and small-town local community and the models of macrosocial order], Łódź. 
Ziółkowski M. (1997), 'Interesy i wartości społeczeństwa polskiego w okresie systemowej transformacji' ['Interests and values of Polish society during systemic transformation'], in: Forum Oświatowe 1997, vol. 1-2, special issue 'Polacy na progu...' ['Poles on the threshold']. 